\title{
A Comparison of Treatment lexicality (Real word, Nonword) in the SSR Intervention for Children with SSD
}

\author{
Kyungrang Baik, JinKyong Kang, Rowon Kang, Young Tae Kim \\ Department of Communication Disorders, Ewha Womans University, Seoul, Korea
}

Correspondence: Young Tae Kim, PhD Department of Communication Disorders, Ewha Womans University, 52 Ewhayeodae-gil, Seodaemun-gu, Seoul 03760, Korea Tel: $+82-2-3277-2120$

Fax: $+82-2-3277-2122$

E-mail: youngtae@ewha.ac.kr

Received: October 3, 2020

Revised: October 27, 2020

Accepted: November 8, 2020

This study was supported by the Ministry of Education of the Republic of Korea and the National Research Foundation of Korea (No. NRF2018S1A3A2075274).

\begin{abstract}
Objectives: This study focuses on finding out which of the two treatments (real word, nonword) is more effective in improving the percentage of consonants correct-revised (PCC-R) of the Children with Speech sound disorders (SSD). Methods: In this study, alternating treatments design (ATD) was used to compare the effect of two treatments. The subjects were 4 children with SSD $(5 ; 0-6 ; 0)$. Subjects took tests about treated and untreated words in baseline, intervention, maintenance phases. In the intervention phase, each subject was trained twice a week for 20 sessions, and if a subject achieved $80 \%$ or higher target phoneme PCC-R ending for three consecutive sessions, the intervention program was completed. Additionally, a follow-up survey was carried out four weeks after the intervention program was completed by evaluating the treated and untreated words for three consecutive sessions to assess the maintenance effect. Results: All subjects were found to have a higher improvement in the target phoneme PCC-R in nonword treatment. In the generalization of untreated words, all subjects indicated an intervention improvement rate difference (IRD) in which the nonword treatment was better than the real word treatment. Comparing the effect of treatments in the maintenance phase, three subjects were found to have same effect size (1.00). and participant 2 indicated that the nonword treatment was more effective in maintaining the intervention effect. Conclusion: When the effectiveness of real word and nonword treatment was compared, in intervention effect, generalization and maintenance, the nonword treatment indicated greater effect than the real word treatment.
\end{abstract}

Keywords: Speech sound disorder (SSD), Articulation intervention, Word lexicality (real words, nonwords), Shared storybook reading (SSR), Percentage of consonants correct-revised (PCC-R), Alternating treatment design (ATD) 말소리장애(speech sound disorders)는 경미한 수준의 혀 짧은 소리를 내는 것에서부터 거의 알아들을 수 없을 정도로 심각한 증 상까지 모두 포함한다(Bernthal, Bankson, \& Flipsen, 2013). 말소리 장애는 아동들에게서 가장 흔하게 나타나는 것으로(King, Hengst, \& DeThorne, 2013; Law, Boyle, Harris, Harkness, \& Nye, 2000), 취 학전기 아동 중에서도 높은 출현율(prevalence)을 보인다(Shriberg, Tomblin, \& McSweeny, 1999; Wren, Harding, Goldbart, \& Roulstone, 2018). 우리나라의 경우, 임상현장에서 설문조사를 하 였을 때 언어치료 기관을 방문한 전체 의사소통장애 아동 중 말소
리장애는 $44.1 \%$ 에 해당하였으며, 그 중 $11.61 \%$ 는 다른 장애를 동반 하지 않은 순수 말소리장애로 나타났다(Kim, Kim, Ha, \& Ha, 2015). 말소리장애의 높은 출현율로 인해 아동의 말소리를 향상시키기 위해 다양한 방향에서 중재가 개발되었으며(Baker \& McLeod, 2011; Wren et al, 2018), 지난 100년동안(예: Swift, 1918) 말소리장애 를 가진 아동들을 위한 수많은 중재 방안이 개발되었다. 약간의 잔 존오류를 보이는 아동들부터 심각하게 알아듣기 어려운 말 명료도 를 보이는 아동들에 이르기까지 다양한 수준을 나타내는 말소리 장애 아동들의 요구를 해결하기 위한 효과적인 접근법이 개발되어 
왔다(Baker, Williams, McLeod, \& McCauley, 2018).

환경적 접근은 아동의 말소리 체계를 변화시키기 위해 일상생활 에서의 상호작용을 통한 접근을 활용하는 것으로, 인위적인 프로 그램은 일상생활에서 연계되거나 적용되지 않아 학습된 행동을 소 거시킬 수 있는 반면, 자연스러운 의사소통 중재 프로그램은 일상 에서도 지속되기 때문에 학습된 행동이 계속적으로 유지될 수 있 다(Kim \& Shin, 2015). 자연스러운 일상생활 환경 내에서 책을 읽 으며 의사소통을 하는 상호작용적 이야기책 읽기는 환경적 중재의 한 갈래로 볼 수 있다. 이는 성인이 아동에게 일방적으로 책을 읽어 주는 것이 아니라, 질문 및 반응 유도하기 등을 통해 함께 상호작용 을 하며 아동의 언어발달이 일어나는 것을 목표로 하고 있다(Song \& Yim, 2018; Whitehurst et al., 1994).

상호작용적 이야기책 읽기를 조음 중재로 활용할 경우, 이야기책 을 읽으며 아동과 성인 사이에서 역동적인 상호작용이 이루어지는 중에, 목표 음소가 충분히 산출될 수 있도록 해야 한다. 자연스러운 맥락에서 목표 음소를 반복적으로 산출하도록 하기 위해서는 이야 기를 구성하는 단어에 목표 음소를 포함시킬 수 있다. 아동들의 연 령 수준에 맞는 이야기들은 일상생활에서 익숙하게 접하는 의미 단어들로 구성되어 있다. 의미 단어는 아동들이 단어의 뜻을 알고, 생활 속에서 사용해 본 경험이 많기 때문에 쉽게 이해하고 따라 읽 기 용이하다. 그러나 의미 단어를 포함하는 이야기를 조음 중재에 활용하기에는 특정 음소를 포함한 단어의 비중을 늘리기 쉽지 않 다는 제한이 있다. 이를 보완하기 위해, 의미 단어와 상반된 어휘적 특성을 갖는 무의미 단어를 중재에 적용할 수 있다.

의미 자극어와 무의미 자극어는 어휘적 표현의 유무에 따라 단 어 어휘성 측면에서 구분되며, 어휘성의 연속성에 따라 단어를 배 열하였을 때 어휘적 표현을 나타내는 의미 자극어는 한쪽 끝에, 어 휘적 표현을 나타내지 않는 무의미 자극어는 반대쪽에 위치하게 된 다(Cummings, Hallgrimson, \& Robinson, 2019). '단어 어휘성 (word lexicality)'이란 모든 단어가 지니고 있는 다양한 어휘적 특 성을 의미하는 것으로, 단어의 습득 연령, 사용 빈도, 인접 밀도 등 에 따라 구분된다(Storkel, 2018). 의미 자극어를 사용한 중재를 하 는 경우, 실생활에서 의미 자극어를 듣고 연습할 가능성이 있으며, 어휘적 특성으로 인해 낯선 단어보다 더 큰 음운론적 변화를 유발 할 수 있다(Gierut, Morrisette, \& Ziemer, 2010; Storkel \& Morrisette, 2002). 무의미 자극어는 어휘적 변수와 음운론적 변수 등을 쉽게 통제할 수 있으며, 아동의 사전 경험이나 단어의 의미와 관련 된 잠재적 편향을 피할 수 있다(Bryan \& Howard, 1992; Leonard, Newhoff, \& Mesalam, 1980). 또한 무의미 자극어를 사용하면 아동 이 목표 음소의 발음에만 집중하도록 할 수 있기 때문에(Cum- mings et al., 2019; van Riper, 1939), 인지 처리 요구를 줄이는데 도 움이 될 수 있다(Cummings \& Barlow, 2011; Gerber, 1973).

의미 자극어와 무의미 자극어를 이야기책 안에 포함하여 상호 작용적 이야기책 읽기를 활용한 조음 중재에 적용할 경우, 각 자극 어의 강점으로 인해 중재 효과에서 차이가 나타날 수 있다. 상호작 용적 이야기책 읽기를 통한 조음 중재 시, 의미 자극어를 포함한 이 야기는 목표 음소를 포함한 자연스러운 흐름을 갖는 이야기로 만 들어진다. 무의미 단어를 포함한 이야기는 생소한 단어로 아동들 이 이야기 이해에 어려움을 겪지 않도록 무의미 자극어를 등장인 물 및 사물의 이름으로 사용하며, 그로 인해 어떠한 이야기든 변형 하여 활용할 수 있다. 서로 다른 특징과 강점을 지닌 두 자극어를 활용한 치료 방법을 비교하여 실시할 때, 둘 중 더욱 효과적인 방법 을 찾을 수 있을 것이다.

이에 따라, 본 연구에서는 상호작용적 이야기책 읽기를 조음 중 재에 적용하여, 중재 시 목표 음소의 자음정확도 및 중재의 일반화 와 유지 효과에 어떠한 영향을 미치는지 확인하고자 한다. 또한 이 야기책 안에 포함되는 목표 음소를 각각 의미 자극어 또는 무의미 자극어와 연결하여, 조음 중재에서 어떤 자극어가 중재 효과 및 일 반화, 유지 효과에 더욱 효과적일지 비교하고자 한다. 본 연구의 질 문은 다음과 같다.

1. 상호작용적 이야기책 읽기를 활용한 조음 중재 시, 단어 어휘 성에 따른 의미 자극어 훈련 방법과 무의미 자극어 훈련 방법 중, 취학전기 말소리장애 아동의 목표 음소 자음정확도 향상 에 더 효과적인 훈련 방법은 무엇인가?

2. 두 훈련 방법 중, 취학전기 말소리장애 아동의 자음정확도 일 반화에 더 효과적인 훈련 방법 무엇인가?

3. 두 훈련 방법 중, 중재가 종료된 이후에도 중재 효과가 유지되 는데 더 효과적인 훈련 방법은 무엇인가?

\section{연구방법}

\section{연구대상}

본 연구의 대상은 서울 지역에 거주하는 취학전기 말소리장애 아동 4명이다. 대상아동 선정 기준은 (1) 부모 및 교사, 혹은 관련 전 문가로부터 발음에서의 어려움이 보고된 아동, (2) 만 5;0 6;0 사이 연령의 아동, (3) 한국 비언어 지능검사-2 (K-CTONI-2; Park, 2014) 의 도형척도 검사 결과, 지능지수가 80 이상인 아동, (4) 수용·표현 어휘력 검사(REVT; Kim, Hong, Kim, Jang, \& Lee, 2009)의 수용 어휘력 검사 결과, $-1 \mathrm{SD}$ 이상인 아동, (5) 우리말 조음·음운 평가 (UTAP2; Kim, Shin, Kim, \& Ha, 2020)을 통해 검사하였을 때 -2 
$\mathrm{SD}$ 미만에 속하는 아동, (6) 심각한 신체, 정서, 시·청각적 감각 기능 에 문제가 없는 아동이다. 선정 기준과 관련한 대상아동의 정보는 Table 1에 제시하였다.

\section{평가과제}

평가과제는 중재 단계에서 아동이 읽는 이야기에 포함되어 자연 스럽게 반복적으로 접하는 훈련단어와 일반화 효과를 비교하기 위 해 별도의 훈련이 제공되지 않는 비훈련단어로 구성된다. 훈련단어 는 목표 음소별로 연결된 중재 방법(의미 자극어, 무의미 자극어)에 따라 구성된 세 가지 이야기에서 같은 비율로 목표 음소 별 주요 단 어를 20개씩 선정하여 목록화하였으며, 그 안에 25개의 목표 음소 가 포함되도록 하였다. 훈련단어에 포함되는 목표 음소와 결합하 는 모음은 대다수의 표준어 화자들이 사용하는 실제 단모음 체계

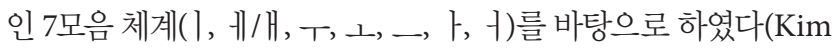
\&Shin, 2015). 비훈련단어는 각 아동별로 목표 음소와 연결되지 않 은 훈련 방법(예: / 시를 의미 자극어 훈련 방법으로 훈련하는 경우, 무의미 자극어 훈련방법에 해당함)의 훈련단어 목록을 사용하였 으며, 중재에서 사용하는 이야기에 포함되지 않도록 하였다. 평가과 제는 Appendix 1에 제시된 단어 목록과 같다.

평가과제에 포함되는 목표 음소는/ㄹ/와/시로 선정하였으며, 대상아동별 목표 음소와 중재 자극어 조합은 Table 2 와 같다. 이는
표준화된 말소리 검사(UTAP2) 결과에서 아동들이 공통적으로 보 인 오류 음소 및 음소 습득 연령(Kim, 1996)을 반영한 것으로, 목표 음소는 현재 아동들의 음소 목록(Phonemic inventory)에 포함되 지 않으면서(Miccio, Elbert, \& Forrest, 1999; Cummings et al., 2019), 아동들이 나타낸 여러 오류 음소 중, 음소 습득 연령 및 음소 의 복잡성 이론에 근거하여 선택되었다. 또한 두 가지 중재의 효과 성을 비교하기 위해 음소 간 공통적인 음운 자질을 갖는 경우를 최 대한 배제하였으며, 조음위치 및 조음방법이 같은 음소의 경우, 평 음을 우선적으로 고려하였다(예: / ㅅ/와 / 씨는 아동들이 공통적으 로 보인 오류 음소이나, 목표 음소 선정 시 평음인 /시를 우선적으 로 고려하였다.).

\section{중재 프로그램}

본 연구의 중재 프로그램은 아동들에게 친숙한 애니메이션의 장 면을 활용하여 이야기의 장면을 구성하고, 치료사와 아동이 함께 이야기를 읽은 뒤 반응 유도 질문을 통해 이야기에 대해 함께 상호 작용한다. 반응 유도 질문은 상호작용적 이야기책 읽기를 하면서 연구자가 질문을 하여 아동이 자연스럽게 훈련단어를 산출할 수 있도록 하는 언어적 문맥을 제공하는 것으로(Kim \& Kim, 2004), 각 이야기는 10 개의 반응 유도 질문을 포함하고 있다. 10 개의 질문 중 9 개는 이야기에 직접 제시된 사실적 정보 이해 관련 질문이며, 1

Table 1. Subjects' characteristics

\begin{tabular}{|c|c|c|c|c|}
\hline Characteristic & Subject 1 & Subject 2 & Subject 3 & Subject 4 \\
\hline Gender & Male & Female & Female & Female \\
\hline Age (yr;mo) & $6 ; 0$ & $5 ; 11$ & $5 ; 0$ & $5 ; 0$ \\
\hline Nonverbal $10^{\mathrm{a}}$ & 104 & 100 & 118 & 114 \\
\hline Receptive vocabulary ${ }^{b}$ & 50\%ile & $30-40 \%$ ile & 100\%ile & 100\%ile \\
\hline UTAP PCC-R ${ }^{\mathrm{c}}$ & $75.00 \%$ & $85.42 \%$ & $77.08 \%$ & $77.08 \%$ \\
\hline \multicolumn{5}{|l|}{ Phonemes error } \\
\hline Consonants in word-initial & 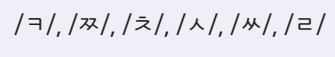 & |ネ|, |ㅆ, /ᄉ/, // & 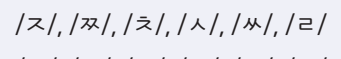 & 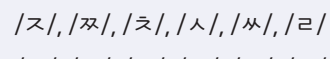 \\
\hline Consonants in word-medial & |ス|,|双|,|ネ|,|ノ|,|从|,|ᄅ| & |찌,/ᄉ|,/ㄹ| & 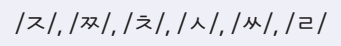 & 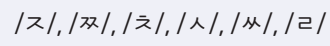 \\
\hline
\end{tabular}

aKorean version of Comprehensive Test of Nonverbal Intelligence second edition (Park, 2014), 'beceptive \& Expressive Vocabulary Test (Kim, Hong, Kim, Jang, \& Lee, 2009), Urimal Test of Artification and Phonology 2 (Kim, Shin, Kim, \& Ha, 2020).

PCC-R= percentage of consonants correct-revised.

Table 2. Example of assessment tasks for each subject

\begin{tabular}{|c|c|c|c|c|c|c|}
\hline \multirow[b]{2}{*}{ Treatment } & \multicolumn{3}{|c|}{ Subject 1, 3} & \multicolumn{3}{|c|}{ Subject 2, 4} \\
\hline & Phoneme target & Treated words & $\begin{array}{c}\text { Generalization } \\
\text { (Untreated words) }\end{array}$ & Phoneme target & Treated words & $\begin{array}{c}\text { Generalization } \\
\text { (Untreated words) }\end{array}$ \\
\hline Real word treatment & /人/ & RW & NW & /ᄅ/ & RW & NW \\
\hline Nonword treatment & /ᄅ/ & NW & RW & /人 / & NW & RW \\
\hline
\end{tabular}

RW= Real words; NW= Nonwords. 
개의 질문은 자신의 경험과 연결 짓는 질문이다. 모든 질문은 아동 이자연스럽게 목표음소를 포함한 단어를 산출하도록 이끈다.

중재 프로그램에 포함되는 의미 자극어 및 무의미 자극어 훈련 방법은 단어 어휘성 측면에서 대조되는 자극어를 사용하여 훈련 한다는 점에서 가장 큰 차이점을 보인다. 의미 자극어 훈련 방법은 의미 자극어를 포함한 이야기를 읽는 과정 중 반복하여 듣고 산출 하는 것이다. 의미 자극어는 만 5-6세의 취학전기 아동들이 의미를 이해하며 실생활에서 자주 사용하는 단어를 중심으로, 한국판 맥 아더-베이츠 의사소통 발달평가(K M-B CDI; Pae \& Kwak, 2011)의 단어 목록과 등급별 국어교육용 어휘(Kim, 2003), 발달장애 학생 들을 위한 교육용 어휘 목록(Kweon, Song, \& Jeon, 2017), 3-8세 아 동의 내용어 발달 연구(Choi, 2003) 중 목표 음소를 포함하는 단어 들로 선정하였다. 선정된 의미 자극어들은 아동들에게 익숙한 어 휘적 특성을 가진 것으로 가정하여 추가적인 설명 없이 이야기 안 에 제시하였으며, 이야기 안에 포함시킬 때에도 문장을 구성하는 모든 품사의 위치에 들어갈 수 있도록 하였다(예: 깨끗이[깨끄시]: 수식언, 샀어요[사써요]: 용언).

무의미 자극어 훈련 방법은 무의미 자극어를 포함한 이야기를 읽 으며 반복적으로 듣고 산출한다. 무의미 자극어는 아동들에게 친숙 하지 않은 저빈도 어휘의 자, 모음 음운 특성을 변경하여 생성하거 나, 목표 음소와 7모음을 조합하여 국어사전에 포함되지 않는 단어 로 만들었다. 본 중재에서는 이야기 속에 실제 단어를 대신하여 무의 미 자극어를 제시하였으며, 아동에게 단어의 뜻에 대해 설명하도록 요구하지 않았다(Cummings et al., 2019). 무의미 자극어 훈련 방법 은 아동의 이야기 이해를 돕기 위해 인물의 이름 및 반복적으로 제 시되는 사물의 이름에만 무의미 자극어를 사용하여 아동이 이야기 이해에 어려움이 없도록 하였다(예: 우르둘라: 체언(이야기의 등장 인물 이름), 자라이드: 체언('미끄럼틀을 의미하는 단어로 사용함)).

\section{회기 구성}

본 프로그램은 치료사와 아동이 함께 그림을 보며 소리내어 이 야기를 읽는 것으로 이루어진다. 치료사가 이야기를 한 줄 읽으면 그 내용을 듣고 아동이 따라 읽는다. 목표 음소를 포함한 단어가 나왔을 때에는 치료사가 그림 등을 가리키며 아동이 단어를 한 번 더 말할 수 있도록 한다. 이야기를 읽은 뒤에는 반응 유도 질문을 통 해 대화를 주고받으며 자연스럽게 목표 음소를 포함한 단어를 여 러차례 말할수 있도록 한다.

전체 중재 회기가 진행되는 동안 아동의 수행에 따라 회기 내 활 동의 단계가 진행되었다. 각 단계는 반드시 모든 단계를 필수적으 로 진행해야 하는 것이 아니며, 아동의 수행 정도에 따라 유연하게
반영된다.

1 단계는 연구자가 아동에게 새로운 이야기를 소개하며 흥미를 가질 수 있도록 한다. 연구자와 아동은 함께 그림을 보며 그림 속장 면에 대해 자유롭게 생각을 주고받고, 이야기에 포함된 단어에 대 해 이야기를 나눈다. 1 단계 동안 매 회기 새로운 이야기를 접하며 이야기에 친숙해진 뒤, 2-4단계에서는 같은 이야기를 반복하여 읽 으며 아동이 점차적으로 이야기에 익숙해지며 즐길 수 있도록 한 다. 2 단계에서는 단어 단위 따라 읽기를 통해 이야기를 소리 내어 따라말한다. 아동이 그림을 보며 자발적으로 단어 단위의 표현을 하는 경우, 연구자는 아동의 발화를 반복하여 산출한다. 2 단계부 터 반응 유도 질문을 사용하여 자연스럽게 목표 음소를 포함한 발 화를 주고받을 수 있도록 한다. 3 단계부터는 아동의 자발적 표현에 대해 발화를 확장.확대하여 말해준다. 4단계에서는 아동도 치료사 에게 반응 유도 질문을 해보도록 한다. 질문과 반응을 서로 주고받 는 상호작용적 이야기책 읽기 활동을 통해 자연스럽게 목표 음소 를 반복 산출하도록 한다.

\section{이야기책 구성}

이야기책은 글자 없이 그림만으로 이루어져 있어서 아동들이 글 자를 읽는 것에 대한 부담을 줄이고, 치료사가 읽어주는 내용을 듣 고 따라말하는 데 집중할 수 있도록 한다. 모든 이야기는 스물 네 개 의 장면으로 이루어진다. 이야기는 훈련 방법에 따라 의미 자극어 이야기와 무의미 자극어 이야기로 구분되며, 동일한 그림과 이야기 구조에 각 훈련 방법에 맞는 목표음소를 포함한 단어를 넣는다.

이야기는 각 목표 음소 및 중재 방법별로 세 가지씩 만들어졌으 며, 3 회기마다 주기적으로 반복하여 읽는다. 이는 상호작용적 이야 기책 읽기의 특징인 '같은 책 반복하여 읽기'를 반영한 것으로, 아 동들은 같은 책을 여러 차례 반복해서 읽는 것을 즐기며, 새로운 것 을 학습할 때에는 반복적인 노출이 아동에게 도움이 된다. 같은 이 야기책을 반복하여 읽기는 아동이 예측 가능하며, 친숙하고, 즐거 운 맥락에 노출될 수 있도록 한다(Ezell \& Justice, 2005).

\section{실험설계}

본 연구는 단일 대상 연구 설계(single-subject research design) 중 하나인 교대 중재 설계(alternating treatment design, ATD)로 설 계되었다. 이 설계는 여러 중재를 교대로 실시하여 중재 간 효과를 비교하는 연구방법으로(Lee, Park \& Kim, 2000), 본 연구에서는 중 재에서 사용하는 자극어를 단어 어휘성에 따라 다르게 하여, 중재 효과를 비교하고자 하였다.

교대 중재 설계에서는 비교 중재 간의 적용시간의 균형을 맞추기 
위해 비교하고자 하는 중재들을 빠른 간격으로 교대하여 적용한 다(Lee et al., 2000). 본 연구에서는 교대 중재 설계를 통해 비교하 는 두 자극어를 사용한 중재를 하루 중 시간 간격을 두어 각 1 회기 씩 진행되도록 하였으며, 중재의 순서에 의한 영향을 줄이기 위해 균형배치(counterbalance)를 통해 매 회기마다 먼저 시작하는 훈련 방법을 바꾸어서 번갈아가며 실시하였다.

\section{실험절차}

본 연구의 실험절차는 기초선, 중재, 유지 단계 모두 일주일에 2 회기씩 진행되었으며, 대상 아동 모두 회기 간 간격을 동일하게 설 정하였다. 실험의 전 과정은 제 1 저자가 실시하였다.

\section{기초선 단계}

기초선 단계는 각 아동의 중재 전 수행 수준을 파악하는 단계로, 연속 3 회기의 안정된 기초선 자료가 수집되면 중재 회기로 넘어가 도록 하였다. 치료사가 목표 음소가 포함된 단어목록을 읽어보도 록 하여 정오반응을 기록하는 방식으로 진행하였으며, 각 아동에 게 회기 당 3 번의 목표 단어 산출 기회를 제공하였다. 기초선 단계 의 1 회기에서는 의미 자극어에 한하여 각 단어를 따라말한 뒤, 동 작과 함께 문장완성형 구두 질문(예: '세수'를 유도하기 위해 - "물 로 어푸어푸 $\bigcirc \bigcirc$ 를 했어요”)을 하며 아동의 단어 의미 이해 여부 를 파악하였다. 평가 시 아동의 반응에 대해서는 어떠한 피드백도 제공하지 않았으며, 기초선에서의 수행이 연속해서 3 회기 이상 안 정을 보였을 때 중재 단계에 도입하였다.

\section{중재 단계}

중재 단계에서는 두 가지 중재가 번갈아가며 제공되며 두 중재는 한 세트(set)로 하여 총 20회기로 진행된다. 중재 단계가 끝나기 전 에 아동의 수행이 사전에 정해 놓은 준거(자음정확도 $80 \%$ 이상)에 연속 3 회기 동안 도달하는 경우에는 남은 회기가 있더라도 중재 단 계를 마무리한다. 한 회기는 훈련 방법당 총 30 분으로 이루어지며, 교대 중재 설계로 하루에 두 번의 회기가 진행된다. 회기 시작 후 10 분 간 평가과제를 사용하여 평가하며, 그 후 이야기책을 읽으며 중 재 활동을 한다. 이야기책을 읽으며 아동이 오류를 보였을 때에는 구어적 단서 등을 제공하여 반복하여 읽을 수 있도록 하였으며, 의 미 및 무의미 자극어 훈련 방법 모두 동일한 연습 기회가 주어졌다.

\section{유지 단계}

유지 단계는 중재 종결 후 시간이 지난 후에도 중재 효과가 지속 되는지 확인하는 단계로 중재 종결 후 4 주 뒤에 3 회기 이상 실시한
다. 유지 회기의 활동은 기초선 회기와 동일하게 진행한다.

\section{자료의 측정 및 분석}

자료의 측정

매 회기 중재 시작 전, 기초선과 동일한 조건에서 훈련단어 및 일 반화 단어, 문장 목록을 통해 대상아동의 말소리 능력 향상 정도를 평가하였다. 자료의 측정은 자음정확도(percentage of consonants correct, PCC)를 기준으로 실시하였다. PCC는 왜곡을 오반응으로 여겨 말소리를 민감하게 평가하며, 개정자음정확도(percentage of consonants correct-revised, PCC-R)는 왜곡을 정반응으로 간주하 여 전반적인 중증도를 반영한다(Ha, Kim, Kim, \& Shin, 2019). Shriberg, Austin, Lewis, McSweeny 그리고 Wilson (1997)의 연구 에서는 말소리장애 아동들이 주로 보이는 오류 유형인 생략, 대치 만을 오류로 보는 PCC-R이 말소리장애 아동들의 말소리 능력을 평가하는데 적합하다고 하였다. 이를 바탕으로 본 연구에서는 PCC-R을 사용하여 아동들의 말소리 능력을 평가하였다.

\section{중재의 효과 크기 분석}

본 연구에서는 중재의 효과 크기를 분석하여 두 중재 중 더 효과 적인 중재를 찾기 위해 중재 효과 크기(Improvement Rate Difference, IRD) 분석 방법을 사용하였다. IRD는 두 개의 IR 사이의 차 이를 계산하는 것으로, 각 단계의 IR은 '향상된 자료점'의 수를 해 당 단계의 총 자료점으로 나누어서 하였다(Parker, Vannest, \& Brown, 2009).

\section{평가자 간 신뢰도}

본 연구의 평가과제에서의 자음정확도에 대한 신뢰도를 검증하 기 위해 평가자 간 신뢰도 분석을 실시하였다. 연구자와 말소리장 애 아동 치료 경험이 있는 2 급 언어재활사 1 인이 평가자 간 신뢰도 분석에 참여하였다. 연구자는 평가자에게 PCC-R로 평가과제를 분 석하는 방법을 설명하였으며, 평가자는 무작위로 선택된 기초선 1 회기, 중재 2 회기, 유지 1 회기의 자료를 독립적으로 평가하였다. 평 가자 간 신뢰도는 두 평가자 간의 일치도로 측정하였다. 의미 자극 어 훈련 방법은 대상아동별로 기초선 단계에서 96.4-97.5\%, 중재 단계에서는 97.4-100\%, 유지 단계에서는 97.5-100\% 일치하였으며, 무의미 자극어 훈련 방법은 기초선 단계에서 96.2-98.3\%, 중재 단 계에서 98.3-100\%, 유지 단계에서는 97.2-100\% 일치하였다.

\section{중재충실도}

본 연구의 중재충실도를 알아보기 위해 2 급 언어재활사 1 인이 무 
Table 3. Content validity of intervention program

\begin{tabular}{|c|c|c|c|c|c|c|c|}
\hline \multirow{2}{*}{ Treatment } & \multirow{2}{*}{ Assessment contents } & \multicolumn{3}{|c|}{ /ᄉ / } & \multicolumn{3}{|c|}{ // } \\
\hline & & ${ }^{\mathrm{a}} \mathrm{A}$ & ${ }^{\mathrm{a} B}$ & ${ }^{\mathrm{a} C}$ & ${ }^{\mathrm{b}} \mathrm{D}$ & ${ }^{\mathrm{b}} \mathrm{E}$ & ${ }^{\mathrm{b}} \mathrm{F}$ \\
\hline \multirow[t]{3}{*}{ Real word } & Story & 4.80 & 4.87 & 4.80 & 4.80 & 4.87 & 4.80 \\
\hline & Picture & 5.00 & 5.00 & 4.78 & 5.00 & 5.00 & 4.78 \\
\hline & Response-induced question & 4.78 & 4.78 & 4.78 & 4.67 & 4.78 & 4.67 \\
\hline \multirow[t]{3}{*}{ Nonword } & Story & 4.67 & 4.60 & 4.67 & 4.87 & 4.93 & 4.80 \\
\hline & Picture & 5.00 & 5.00 & 4.78 & 5.00 & 5.00 & 4.89 \\
\hline & Response-induced question & 4.78 & 4.78 & 4.78 & 4.67 & 4.89 & 4.67 \\
\hline
\end{tabular}

${ }^{\mathrm{a}} \mathrm{A},{ }^{\mathrm{a}} \mathrm{B},{ }^{\mathrm{a}} \mathrm{C}=$ Story included target phoneme $/ \boldsymbol{\wedge} /{ }^{\mathrm{b}} \mathrm{D},{ }^{\mathrm{b}} \mathrm{E},{ }^{\mathrm{b}} \mathrm{F}=$ Story included target phoneme $/ \mathrm{e} / \mathrm{.}$

작위로 선정한 중재 단계의 회기 자료를 보고 중재 충실도를 평가 하였다. 대상자별로 기초선, 중재, 유지 단계에서 각 1 회기씩 선택하 여 각 아동별로 총 3 회기를 측정하였으며, 중재 순서의 균형 및 일 관성 등을 묻는 평가지를 통해 예/아니오로 답변하도록 하였다. 평 가 결과, 대상아동 1 부터 대상아동 4 까지의 중재충실도가 모두 $100 \%$ 로 산출되었다.

\section{내용타당도}

내용타당도를 측정하기 위해 중재 시작 전 1 급 언어재활사 3 명에 게 온라인 설문지를 제공하여 평가하도록 하였으며, 결과는 Table 3 과 같다. 설문지는 이야기, 그림 및 반응 유도 질문에 대해 이해의 명료성, 자료의 흥미성, 목표 음소 표현의 적절성 등에 대한 질문으 로 각 이야기마다 총 11 문항(이야기 5 문항, 그림 3 문항, 반응 유도 질문 3 문항)으로 구성되었다, 평정은 Likert 5 점 척도를 사용하여 전혀 그렇지 않다(1)-매우 그렇다(5) 중에서 평가하였다.

\section{연구결과}

\section{두 훈련 방법이 자음정확도 향상에 미치는 효과 비교}

상호작용적 이야기책 읽기를 활용한 조음 중재에서의 의미 및 무 의미 자극어 훈련 방법을 4 명의 취학전기 말소리장애 아동을 대상 으로 실시한 결과, 네 아동 모두 두 훈련 방법 중 무의미 자극어 훈 련 방법에서 더 큰 효과를 보이는 것으로 나타났다. 목표 음소 자음 정확도에 대한 대상아동별 수행 결과는 Figure 1에 제시하였으며, 평균, 범위 및 효과크기(IRD)는 Table 4와 같다. 대상아동 1, 2, 3은 사전에 정한 준거를 충족하여 8-10회기 후 중재 단계가 종결되었다. Parker 등(2009)의 기준으로 무의미 자극어 훈련 방법과 의미 자극 어 훈련 방법의 중재 $\mathrm{IRD}$ 를 비교하였을 때, 무의미 자극어 훈련 방 법은 모두 .75 이상으로 매우 큰 효과 크기를 나타내었으며 의미 자 극어 훈련 방법은 모두 .50-.70 사이로 중간 크기의 효과를 나타내
어 무의미 자극어 훈련 방법이 의미 자극어 훈련 방법보다 더 큰 효 과를 갖는 것을 확인할 수 있었다. 대상아동 4 는 중재 종결 준거를 충족하지 않아서 사전에 계획한 총 중재 회기를 모두 진행하여 마 무리하였다. 무의미 자극어 훈련방법의 중재 IRD .67, 의미 자극어 훈련방법의 중재 IRD .55로 두 훈련 방법의 IRD가 모두 중간 정도 의 효과 크기를 갖지만, 무의미 자극어 훈련 방법의 중재 IRD가 의 미 자극어 훈련 방법보다 근소한 차이로 더 큰 효과 크기를 보인다.

\section{두 훈련 방법의 자음정확도 측면에서의 일반화 효과 비교}

의미 및 무의미 자극어 훈련의 일반화에서의 효과에 대해 비교 하였다. 결과는 Figure 2에 제시하였으며, 평균, 범위 및 IRD는 Table 5 와 같다. 비훈련단어로의 일반화에서는 네 명의 대상아동 모 두 무의미 자극어 훈련 방법이 의미 자극어 훈련 방법보다 더 큰 중 재 IRD를 나타내었다. 유지 IRD의 경우 대상아동 $1,3,4$ 는 두 훈련 방법 모두 1.00 으로 매우 큰 효과 크기가 나와서 두 훈련 방법 간 비 교가 어려웠으며, 대상아동 2 에서만 무의미 자극어 훈련 방법에서 1.00 , 의미 자극어 훈련 방법에서 33 으로 무의미 자극어 훈련 방법 에서의 비훈련단어 일반화가 더 효과적인 것으로 나타났다.

\section{두 훈련 방법의 자음정확도 측면에서의 유지 효과 비교}

유지 단계에서의 대상아동별 수행 결과는 Table 4 와 같다. 유지 단계에서 의미 및 무의미 자극어 훈련 방법 중 어떤 훈련 방법이 더 효과적인지 살펴보았을 때, 대상아동 $1,3,4$ 는 두 가지 훈련 방법에 서 동일한 효과크기를 나타내어 두 훈련 방법 모두 효과가 있는 것 으로 확인되었으며, 대상아동 2 는 무의미 자극어 훈련 방법의 유지 $\mathrm{IRD}$ 는 1.00 으로 매우 큰 효과 크기를 갖지만, 의미 자극어 훈련 방 법의 유지 IRD는 매우 작은 효과 크기를 나타내어, 무의미 자극어 훈련 방법이 의미 자극어 훈련 방법보다 중재 효과가 유지되는데 더 효과적인 것으로 나타났다. 


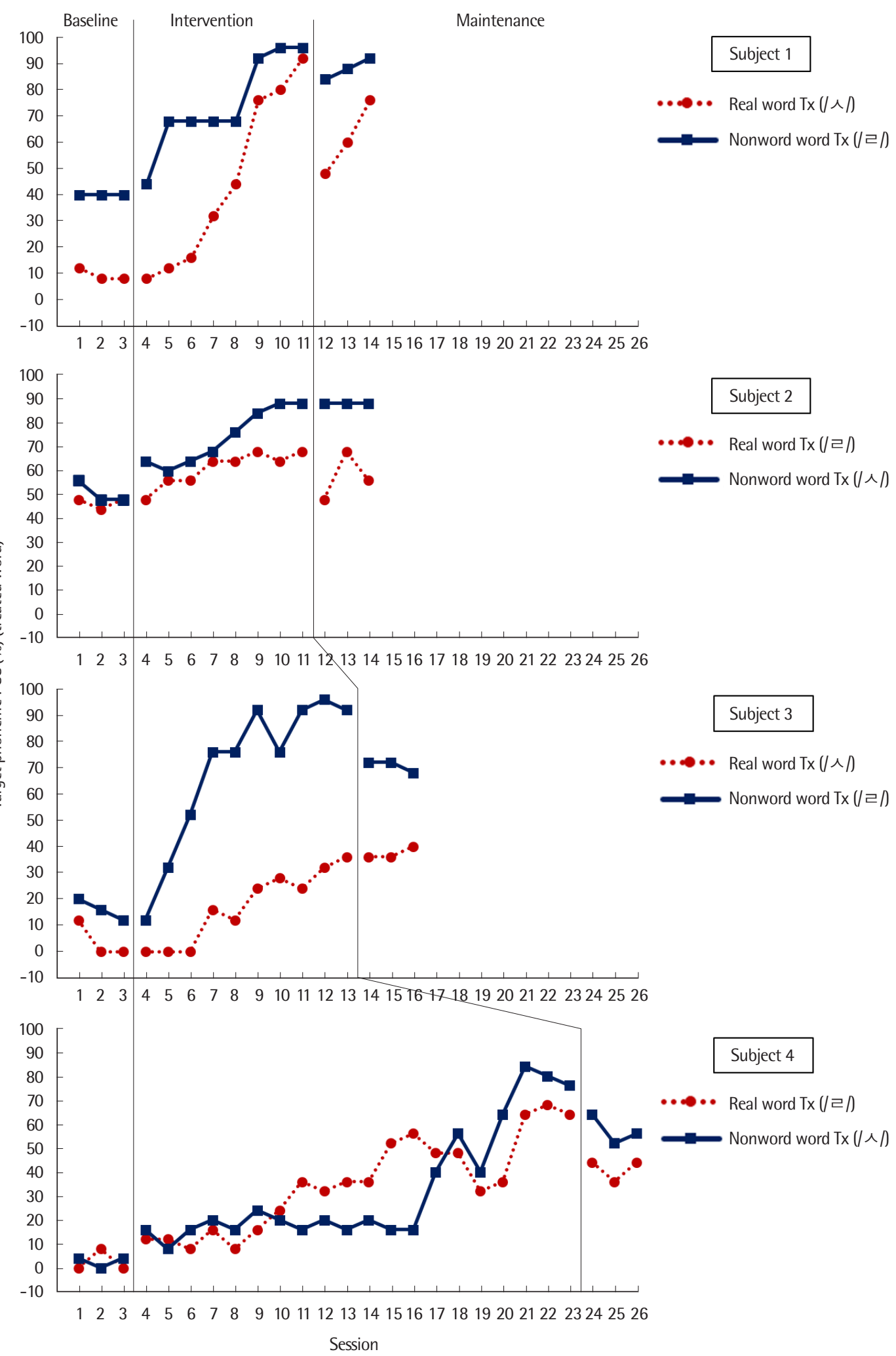

Figure 1. The comparison of the intervention effect of treatments (real word, nonword) as treated words (\%). 
Table 4. Result of the target phoneme PCC (treated word) according to the intervention phase

\begin{tabular}{|c|c|c|c|c|}
\hline \multirow{2}{*}{ Subject } & \multirow{2}{*}{ Treatment } & \multicolumn{3}{|c|}{ Intervention phase } \\
\hline & & Baseline & Intervention & Maintenance \\
\hline \multirow[t]{8}{*}{ Subject 1} & Real word & & & \\
\hline & \# of sessions & 3 & 8 & 3 \\
\hline & Mean (range) & $9.33(8-12)$ & 45.00 (8-92) & $61.33(48-76)$ \\
\hline & $\mathrm{IRD}$ & - & .62 & 1 \\
\hline & Nonword & & & \\
\hline & \# of sessions & 3 & 8 & 3 \\
\hline & Mean (range) & $40.00(40-40)$ & $83.50(44-96)$ & 88.00 (84-92) \\
\hline & $\mathrm{IRD}$ & - & 1 & 1 \\
\hline \multirow[t]{8}{*}{ Subject 2} & Real word & & & \\
\hline & \# of sessions & 3 & 8 & 3 \\
\hline & Mean (range) & 46.67 (44-48) & $61.00(48-68)$ & 57.33 (48-68) \\
\hline & IRD & - & .54 & .33 \\
\hline & Nonword & & & \\
\hline & \# of sessions & 3 & 8 & 3 \\
\hline & Mean (range) & $50.67(48-56)$ & 74.00 (60-88) & 88.00 (88-88) \\
\hline & IRD & - & 1 & 1 \\
\hline \multirow[t]{8}{*}{ Subject 3} & Real word & & & \\
\hline & \# of sessions & 3 & 10 & 3 \\
\hline & Mean (range) & $4.00(0-12)$ & $17.20(0-36)$ & $37.33(36-40)$ \\
\hline & IRD & - & 6 & 1 \\
\hline & Nonword & & & \\
\hline & \# of sessions & 3 & 10 & 3 \\
\hline & Mean (range) & $16.00(12-20)$ & 69.60 (12-92) & 70.67 (68-72) \\
\hline & $\mathrm{IRD}$ & - & .9 & 1 \\
\hline \multirow[t]{8}{*}{ Subject 4} & Real word & & & \\
\hline & \# of sessions & 3 & 20 & 3 \\
\hline & Mean (range) & 2.67 (0-8) & 35.20 (8-68) & 41.33 (36-44) \\
\hline & IRD & - & .55 & .67 \\
\hline & Nonword & & & \\
\hline & \# of sessions & 3 & 20 & 3 \\
\hline & Mean (range) & 2.67 (0-4) & 33.20 (8-84) & 57.33 (52-64) \\
\hline & IRD & - & .67 & .67 \\
\hline
\end{tabular}

IRD = below .50: small effect size, .50-.70: moderate effect size, .70-.75: large effect size, over .75: very large effect size (Parker et al., 2009). $\mathrm{IRD}=$ improvement rate difference.

\section{논의 및 결론}

본 연구에서는 상호작용적 이야기책 읽기를 활용한 조음 중재를 의미 자극어 및 무의미 자극어 훈련 방법으로 나누어서 각 목표 음 소를 의미 및 무의미 자극어에 포함하여 두 훈련 방법 중 자음정확 도 향상에 더 효과적인 중재를 알아보고자 하였다. 4 명의 취학전기 말소리장애 아동에게 실시하여 무의미 자극어 훈련 방법이 자음 정확도 향상에 더 효과적임을 확인할 수 있었다. 구체적인 결과는 다음과같다.
첫째, 상호작용적 이야기책 읽기를 활용한 조음 중재에서의 무의 미 자극어 훈련 방법은 의미 자극어 훈련 방법보다 말소리 능력 향 상에 효과적이었다. 대상아동 네 명 모두 무의미 자극어 훈련 방법 에서 중재 IRD 값이 더 크게 나타났다. 다만 대상아동 1 의 경우, 두 중재를 적용하는 목표 음소의 자극반응도가 기초선 단계에서 시각 적으로 뚜렷한 차이를 보이고 있기 때문에 이를 고려해야 할 수도 있다. 그러나 중재 단계 시작 후 중재에 대한 반응이 나타나는 속도 등을 보았을 때에도 무의미 자극어 훈련 방법이 더 효과적이었음 을 확인할 수 있으며, 이는 무의미 자극어를 사용한 중재가 의미 자 


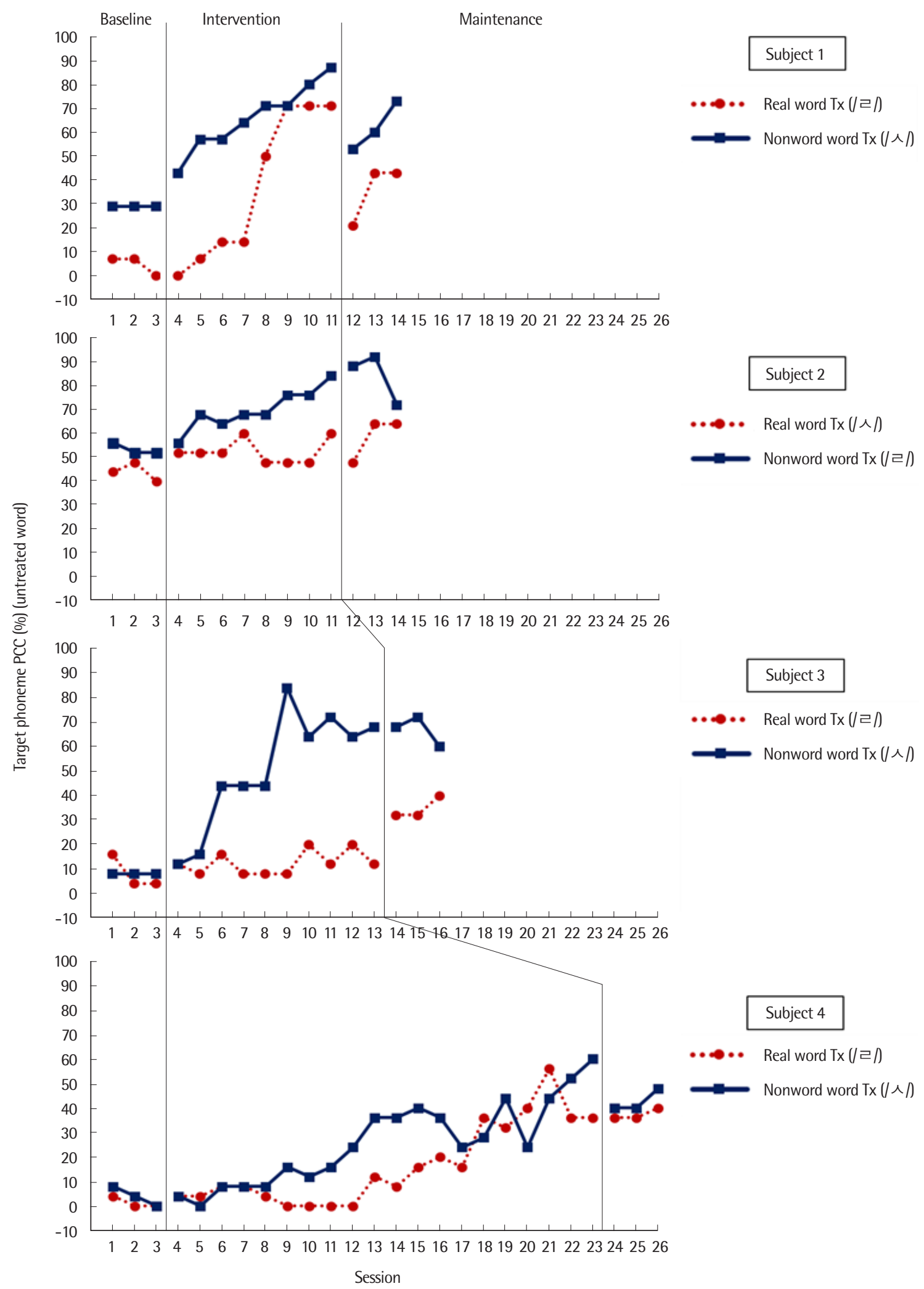

Figure 2. The comparison of the generalization effect of treatments (real word, nonword) as untreated words (\%). 
Table 5. Result of the target phoneme PCC (untreated word) according to the intervention phase

\begin{tabular}{|c|c|c|c|c|}
\hline \multirow{2}{*}{ Subject } & \multirow{2}{*}{ Treatment } & \multicolumn{3}{|c|}{ Intervention phase } \\
\hline & & Baseline & Intervention & Maintenance \\
\hline \multirow[t]{8}{*}{ Subject 1} & Real word & & & \\
\hline & \# of sessions & 3 & 8 & 3 \\
\hline & Mean (range) & $4.67(0-7)$ & $37.25(0-71)$ & 35.67 (21-43) \\
\hline & $\mathrm{IRD}$ & - & .75 & 1 \\
\hline & Nonword & & & \\
\hline & \# of sessions & 3 & 8 & 3 \\
\hline & Mean (range) & $29.00(29-29)$ & $66.25(43-87)$ & $62.00(53-73)$ \\
\hline & IRD & - & 1 & 1 \\
\hline \multirow[t]{8}{*}{ Subject 2} & Real word & & & \\
\hline & \# of sessions & 3 & 8 & 3 \\
\hline & Mean (range) & 44.00 (40-48) & $52.50(48-60)$ & $58.67(48-64)$ \\
\hline & IRD & - & .29 & .33 \\
\hline & Nonword & & & \\
\hline & \# of sessions & 3 & 8 & 3 \\
\hline & Mean (range) & $53.33(52-56)$ & 70.00 (56-84) & 84.00 (72-92) \\
\hline & IRD & - & .87 & 1 \\
\hline \multirow[t]{8}{*}{ Subject 3} & Real word & & & \\
\hline & \# of sessions & 3 & 10 & 3 \\
\hline & Mean (range) & $8.00(4-16)$ & $12.40(8-20)$ & 34.67 (32-40) \\
\hline & IRD & - & .2 & 1 \\
\hline & Nonword & & & \\
\hline & \# of sessions & 3 & 10 & 3 \\
\hline & Mean (range) & $8.00(8-8)$ & $51.20(12-84)$ & 66.67 (60-72) \\
\hline & IRD & - & 1 & 1 \\
\hline \multirow[t]{8}{*}{ Subject 4} & Real word & & & \\
\hline & \# of sessions & 3 & 20 & 3 \\
\hline & Mean (range) & $1.33(0-4)$ & $16.80(0-56)$ & $37.33(36-40)$ \\
\hline & IRD & - & .65 & 1 \\
\hline & Nonword & & & \\
\hline & \# of sessions & 3 & 20 & 3 \\
\hline & Mean (range) & $4.00(0-8)$ & $26.00(0-60)$ & 42.67 (40-48) \\
\hline & IRD & - & .75 & 1 \\
\hline
\end{tabular}

IRD = below .50: small effect size, .50-.70: moderate effect size, .70- .75: large effect size, over .75: very large effect size (Parker et al., 2009). $\mathrm{IRD}=$ improvement rate difference.

극어를 통한 중재보다 더 효과적이었다는 Cummings와 Barlow (2011), Leonard (1973)의 선행연구와 일치한다.

무의미 자극어 훈련 방법의 중재 효과가 더 크게 나타난 것은 여 러 가지 근거에 바탕을 두고 있을 수 있다. 먼저, 두 자극어 훈련 방 법을 이야기에 적용한 품사의 범위가 중재 효과에 영향을 주었을 수 있다. 본 중재에서 무의미 자극어는 아동의 이야기 이해에 어려 움을 주지 않기 위해 체언으로만 포함시켜서 이야기의 주요 등장인 물 및 사물로 제시되도록 하였으며, 의미 자극어는 무의미 자극어 와 동일한 길이의 이야기에 목표 음소를 동일하게 포함시키기 위해
여러 가지 단어를 활용하여 체언, 용언, 수식언 등의 모든 품사로 제 시하였다. 이는 말소리가 지닌 기능적 가치가 말소리 습득에서 중요 한 요인이라는 Ingram (1988)의 기능적 가설과 연결 지어서 해석할 수 있다. 본 중재에서 각 회기마다 의미 자극어와 무의미 자극어의 산출 빈도는 일정하게 균형을 맞추었지만, 중재에 사용되는 이야기 에서 각 자극어가 포함되는 위치 및 기능이 서로 상이한 점이 중재 효과의 차이를 가져올 수 있다는 것이다. 실생활에서의 기능적 가 치는 의미 자극어가 무의미 자극어보다 더 크지만, 중재에서의 기 능적 가치는 연구자가 자극어를 어떤 품사로 배치하였느냐에 따라 
다를 수 있다. 중재에 사용한 이야기책 안에서 무의미 자극어는 체 언의 위치에만 포함되어, 두 자극어 중 기능적 가치가 더 크며 그로 인해 무의미 자극어 훈련 방법의 중재 효과가 더 크게 나타난 것으 로 볼수있다.

또한, 중재 효과의 차이는 말소리장애 아동들이 잘못된 습관으 로 조음하는 기능적 원인(Sim et al., 2011)과 연관 지어서 생각할 수 있다. 본 연구에서 사용한 의미 자극어는 취학전기 아동들이 일상 생활에서 고빈도로 사용하는 단어로, 아동들의 잘못된 조음 습관 이 습관화된 상태에서 산출하던 단어들이다. 본 중재 프로그램과 같은 아동 주도적, 간접적 중재를 통해서는 습관화된 조음 오류가 즉각적으로 수정되기 쉽지 않다. 반면 무의미 자극어는 본 연구를 통해 새롭게 접하게 된 단어이며, 글자 등의 단서와 함께 제공하지 않기 때문에 기존의 지식과 결합될 가능성이 비교적 낮으며, 아동 이 조음방법에만 집중하도록 할 수 있다(van Riper, 1939). 또한 아 동이 치료사의 말을 듣고 따라말하는 것이므로 자동 발화로 인한 습관적인 조음 오류가 나타날 가능성이 의미 자극어에 비해 낮아 질 수 있다. 무의미 자극어는 단어 관련 사전 경험이 없기 때문에 의 미 자극어와 같이 이전에 오조음하였던 부정적인 경험이 남아있지 않다는 Cummings 등(2019) 연구와같은 맥락에서 해석할 수 있다.

마지막으로, 두 훈련 방법의 중재 효과 차이는 무의미 자극어가 아동들에게 흥미롭고 재미있는 요소로 작용하였다는 점이다. 아 동들은 낮설었던 무의미 자극어가 이야기와 연결되는 과정에서 그 에 대한 흥미를 가질 수 있으며(Dewey, 1913; Hulleman, Godes,

Hendricks, \& Harackiewicz, 2010), 흥미와 관심은 성취까지 연결 될 수 있다(Hulleman et al., 2010; Renninger, 2000). 아동들의 반 응을 관찰하였을 때, 아동들은 이야기 안에서 무의미 자극어를 접 하였을 때 '새롭고 즐겁고 익살스러운 것'으로 인식하는 것을 볼 수 있었다. 익숙한 이야기 맥락 안에서 낯선 무의미 자극어가 나타났 을 때, 아동들은 매우 흥미로워하였으며, 그러한 아동들의 반응이 무의미 자극어 훈련 방법의 중재 효과에 영향을 미쳤을 수 있다. 무 의미 자극어에 대한 관심 및 흥미는 대상아동 $1,2,3$ 에게서는 중재 초반부터 지속적으로 관찰되었으며, 대상아동 4 는 중재 중반까지 는 큰 흥미를 보이지 않다가 중재가 진행됨에 따라 서서히 관심을 보였다. 이러한 흥미의 차이는 각 아동의 중재 종결까지 소요된 회 기 수에 영향을 준 것으로 생각할 수 있다. 적극적으로 흥미를 나타 낸 아동들은 예정된 총 회기보다 빨리 준거를 달성하여 중재 단계 가 종결되었다. 그러나 대상아동 4 는 중재 회기 초반에는 중재 활 동 전반에 큰 흥미를 보이지 않으며 두 훈련 방법 모두 낮은 수행을 보이다가 중반부터 서서히 익숙한 의미 자극어 훈련 방법부터 진전 을 보이기 시작했다. 그러나 의미 자극어 훈련 방법은 자음정확도
$60 \%$ 정도 수준에서 더 이상의 진전을 보이지 않으며, 중후반부부 터는 무의미 자극어에 대한 흥미와 함께 중재 효과도 나타나기 시 작하였다. 이러한 차이는 아동들이 낯설거나 새로운 자극을 받아 들일 때의 감정 및 태도와 연관 지을 수 있을 것으로 생각되며, 이에 대해 후속연구에서 무의미 자극어에 대한 아동의 정서적 반응 및 태도에 대해 살펴본다면 보다 구체적인 관련성을 파악할 수 있을 것으로 생각된다.

둘째, 비훈련단어로의 일반화에 있어서도 무의미 자극어 훈련 방법이 의미 자극어 훈련 방법보다 더욱 효과적인 것으로 나타났으 며, 두 훈련 방법 간 효과 크기의 차이는 중재 효과를 비교하였을 때보다 더욱 두드러지게 나타났다. 이는 의미 자극어와 무의미 자 극어의 일반화에 대한 선행연구와 일치한다. Gierut 등(2010)의 연 구에서는 무의미 자극어와 의미 자극어의 일반화 효과에 대해 훈 련단어와 비훈련단어로 나누어서 살펴보았는데, 훈련단어 및 비훈 련단어 모두 무의미 자극어에서 더 높은 정확도로 나타났다. 이는 연구질문 1,2 를 통해 본 연구에서 측정한 것과 같은 결과로 해석할 수있다.

또한 의미 자극어 훈련 방법과 무의미 자극어 훈련 방법의 일반 화 목록이 각각 무의미 자극어와 의미 자극어로 구성되어 있다는 점을 바탕으로, 복잡성 이론(complexity theory)과 연관 지어서 생 각할 수 있다. 복잡성 이론은 복잡하고 더 어려운 자극을 우선적으 로 치료하였을 때, 쉬운 자극부터 치료하는 것보다 일반화 효과가 더 크게 일어난다는 이론이다(Kiran, 2007; Thompson \& Shapiro, 2005). 난이도가 높은 것을 학습하였을 때 난이도가 낮은 것으로 의 일반화는 자연스럽게 일어나지만, 쉬운 것을 학습하였을 때에는 자연스럽게 어려운 것으로 일반화되기 어려울 수 있다. 그러한 관점 에서 무의미 자극어로 훈련을 하고 의미 자극어로 일반화되는 것 이 반대의 경우보다 더 자연스럽게 나타날수 있다.

셋째, 중재 종결 후 유지에서는 세 아동은 두 훈련 방법 모두 큰 효과가 있는 것으로 나타났으나, 대상아동 2 의 경우 무의미 자극어 훈련 방법은 큰 효과가 있는 것으로 나타났으나 의미 자극어 훈련 방법은 우연 수준 이하로 나타나서 중재 효과가 종결 뒤에 유지되 지 않은 것으로 나타났다.

이를 종합하였을 때, 중재 효과 및 일반화, 유지에서 전반적으로 무의미 자극어 훈련 방법이 의미 자극어 훈련 방법보다 큰 효과를 나타내는 것으로 파악할 수 있다. 따라서 조음 중재 방법으로써 상 호작용적 이야기책 읽기 중재에서의 무의미 자극어 훈련 방법이 가 지는 의의는 다음과 같다.

첫째, 무의미 자극어 훈련 방법은 다양한 대상자 및 목표 음소에 따라 쉽게 변형하여 적용할 수 있다는 점에서 의의가 있다. 본 연구 
에서는 대다수의 표준어 화자들이 사용하는 실제 단모음 체계인 7 모음 체계( I, ㄱ/ / / , T, , , 一, F, - - )ㅡㄹㄹ 바탕으로 훈련단어를 만들 었다. 실생활에서의 활용도를 고려하였을 때 매우 유용성이 높을 수 있으며, 다양한 모음 환경에서의 목표 음소 산출을 고르게 중재 할 수 있다. 무의미 자극어는 소리와자극어, 둘 간의 연결이 동시에 학습되기 때문에 음운학습을 강화시킬 수 있으며(Storkel, 2018), 인 지 처리 요구를 줄이기 때문에 보다 많은 자동화된 음소와 단어 산 출을 가능하게 할 수 있을 것이다(Cummings et al., 2019). 또한, 대 상아동의 연령 및 흥미를 고려하여 사용할 이야기를 선정하고, 그 안에 포함되는 내용어들을 목표 음소를 포함한 훈련단어로 바꾸 어 넣는다면 대상자의 특성을 고려한 중재 방법으로 적용할 수 있 을 것이다. 만일 대상아동이 특정 모음 환경에서만 조음 오류가 나 타나는 경우, 아동의 자극반응도 평가 결과에 따라 훈련단어를 만 들어서 집중적인 중재를 할수 있을 것이다.

둘째, 상호작용적 이야기책 읽기 중재는 기존의 조음 중재 방법 보다 아동중심적인 중재 방법이다. 아동이 흥미를 갖는 이야기책 을 사용하여 반복적으로 상호작용적 이야기책 읽기를 실시한다면 아동이 조음 중재에 흥미를 가지고 적극적으로 참여할 수 있을 것 이다. 또한 반응 유도 질문은 아동이 자발적으로 목표 음소를 포함 한 단어를 산출하게 도움으로써 아동이 중재 활동 중 적극적으로 참여하는데 큰 도움이 된다. 다만, 이야기책 읽기 활동에 대한 부정 적인 경험이 있거나 선호도가 낮은 경우에는 이를 통한 중재의 효 과가 기대와는 다르게 나타날 수 있으므로, 이야기책 읽기를 중재 로 사용할 때에는 책읽기에 관한 아동의 성향 및 동기에 대한 평가 가 사전에 실시되어야 하며, 활동의 선호도에 대한 고려가 지속적 으로 이루어질 필요가 있다(Kaderavek \& Justice, 2002).

본 연구의 제한점 및 제언은 다음과 같다. 첫째, 본 연구에는 글 자를 사용하지 않고 듣고 따라말하기로 조음 중재를 하기 위해 취 학전기 아동을 대상으로 중재를 실시하였다. Kim (1992) 연구에서 의 음소 습득 연령을 고려하였을 때,/시를 목표 음소로 중재를 할 경우에는 중재 대상 아동들의 생활연령을 6;0 이상으로 한다면 중 재의 효과가 보다 명확하게 확인할 수 있을 것이다. 둘째, 본 연구에 서는 어두초성 및 어중초성 위치에서의 조음 중재를 실시하여 두 자극어의 효과성을 비교하였다. 종성 위치에서의 목표 음소에 대 한 중재를 하였을 때에도 본 연구와 같이 무의미 자극어에서 더 큰 효과가 나타날지에 대한 후속연구가 필요할 것이다. 셋째, 본 연구 에서는 단일 대상 연구를 통해 4 명의 아동을 대상으로 하였으나, 후속연구에서는 선행연구(Cummings et al., 2019)와 같이 단어 어 휘성에 따라 집단을 나누어서 집단 간 비교를 통한 중재 효과 비교 연구로 더욱 효과적인 중재를 확인해보는 것도 의의가 있을 것이
다. 넷째, 본 연구에서는 연구자와 아동 간의 상호작용적 이야기책 읽기를 통 한 중재 효과 비교를 실시하였는데, 환경적 중재의 특성 을 고려하였을 때, 연구자가 아동의 보호자에게 중재 방법에 대한 부모교육을 실시하여, 아동의 보호자와 아동이 상호작용적 이야 기책 읽기를 하는 것으로 중재 간 효과 비교를 하는 것도 의의가 있 을 것으로 여겨진다.

\section{REFERENCES}

Baker, E., \& McLeod, S. (2011). Evidence-based practice for children with speech sound disorders: Part 1 narrative review. Language, Speech, and Hearing Services in Schools, 42(2), 102-139.

Baker, E., Williams, A. L., McLeod, S., \& McCauley, R. (2018). Elements of phonological interventions for children with speech sound disorders: the development of a taxonomy. American Journal of Speech-Language Pathology, 27(3), 906-935.

Bernthal, J. E., Bankson, N. W., \& Flipsen, P. (2013). Articulation and phonological disorders: speech sound disorders in children. Boston, MA: Pearson.

Bryan, A., \& Howard, D. (1992). Frozen phonology thawed: the analysis and remediation of a developmental disorder of real word phonology. International Journal of Language \& Communication Disorders, 27(4), 343-365.

Choi, E. (2003). Development of Korean children's vocabulary: 3 to 8 years old children oriented (Master's thesis). Korean Nazarene University, Cheonan.

Cummings, A., Hallgrimson, J., \& Robinson, S. (2019). Speech intervention outcomes associated with word lexicality and intervention intensity. Language, Speech, and Hearing Services in Schools, 50(1), 83-98.

Cummings, A. E., \& Barlow, J. A. (2011). A comparison of word lexicality in the treatment of speech sound disorders. Clinical Linguistics \& Phonetics, 25(4), 265-286.

Dewey, J. (1913). Interest and effort in education. Cambridge, MA: Riverside Press.

Ezell, H. K., \& Justice, L. M. (2005). Shared storybook reading. Baltimore, MD: Brookes Publishing.

Gerber, A. (1973). Goal: carryover: an articulation manual and program. Philadelphia, PA: Temple University.

Gierut, J. A., Morrisette, M. L., \& Ziemer, S. M. (2010). Nonwords and generalization in children with phonological disorders. American Journal of Speech-Language Pathology, 19(2), 167-177.

Ha, J. W., Kim, S. J., Kim, Y. T., \& Shin, M. (2019). Develop- mental analysis in Korean children's speech production using percentage of consonants 
correct and whole-word measurements. Communication Sciences and Disorders, 24(2), 469-477.

Hulleman, C. S., Godes, O., Hendricks, B. L., \& Harackiewicz, J. M. (2010). Enhancing interest and performance with a utility value intervention. Journal of Educational Psychology, 102(4), 880-895.

Ingram, D. (1988). The acquisition of word-initial [v]. Language and Speech, 31(1), 77-85.

Kaderavek, J., \& Justice, L. M. (2002). Shared storybook reading as an intervention context: practices and potential pitfalls. American Journal of Speech-Language Pathology, 11(4), 395-406.

Kim, H., \& Kim, Y. (2004). The effects on expansion of semantic relations through the functional reading intervention using storybook for children with language delay. Journal of Speech-Language \& Hearing Disorders, 13(4), 93-115.

Kim, K. H. (2003). Vocabulary use in Korean education according to level. Seoul: PJ Book.

Kim, S. J., Kim, M. J., Ha, S., \& Ha, J. W. (2015). A survey of speech sound disorders in clinical settings. Communication Sciences \& Disorders, 20(2), 133-144.

Kim, S. J., \& Shin, J. Y. (2015). Speech sound disorders. Seoul: Sigmapress.

Kim, Y. (1992). A study of phonological regression in 2-6 years of age(I): omission and addition patterns. Journal of Rehabilitation Science, 10(1), 49-58.

Kim, Y. T. (1996). The percentage of consonant correct (PCC) using picture articulation test in preschool children. Korean Journal of Communication \& Disorders, $1,7-34$.

Kim, Y. T., Shin, M. J., Kim, S. J., \& Ha, J. W. (2020). Urimal test of articulation and phonology-2 (UTAP2). Seoul: Inpsyt.

Kim, Y. T., Hong, G. H., Kim, K. H., Jang, H. S., \& Lee, J. Y. (2009). Receptive \& expressive vocabulary test (REVT). Seoul: Seoul Community Rehabilitation Center.

King, A. M., Hengst, J. A., \& DeThorne, L. S. (2013). Severe speech sound disorders: an integrated multimodal intervention. Language, Speech, and Hearing Services in Schools, 44(2), 195-210.

Kiran, S. (2007). Complexity in the treatment of naming deficits. American Journal of Speech-Language Pathology, 16(1), 18-29.

Kweon, H., Song, J., \& Jeon, B. (2017). A study on the development of vocabulary list for Korean education of students with developmental disabilities. Journal of Special Education for Curriculum and Instruction, 10(2), 89-122. Law, J., Boyle, J., Harris, F., Harkness, A., \& Nye, C. (2000). Prevalence and natural history of primary speech and language delay: findings from a systematic review of the literature. International Journal of Language and Communication Disorders, 35(2), 165-188.

Lee, S. H., Park, E. H., \& Kim, Y. T. (2000). Single subject design: Application in educational and clinical settings. Seoul: Hakjisa.

Leonard, L. B. (1973). Referential effects on articulatory learning. Language and Speech, 16, 45-56.

Leonard, L. B., Newhoff, M., \& Mesalam, L. (1980). Individual differences in early child phonology. Applied Psycholinguistics, 1(1), 7-30.

Miccio, A. W., Elbert, M., \& Forrest, K. (1999). The relationship between stimulability and phonological acquisition in children with normally developing and disordered phonologies. American Journal of Speech-Language Pathology, 8(4), 347-363.

Pae, S., \& Kwak, K. (2011). Korean version of MacArthur-Bates Communicative Development Inventory (K M-B CDI). Seoul: Mindpress.

Park, H. (2014). Korean version of Comprehensive Test of Nonverbal Intelligence second edition (K-CTONI-2). Seoul: Mindpress.

Parker, R. I., Vannest, K. J., \& Brown, L. (2009). The improvement rate difference for single-case research. Exceptional Children, 75(2), 135-150.

Renninger, K. A. (2000). Individual interest and its implications for understanding intrinsic motivation. In C. Sansone \& J. M. Harackiewicz (Eds.), Intrinsic and extrinsic motivation: the search for optimal motivation and performance (p. 373-404). San Diego, CA: Academic Press.

Shriberg, L. D., Tomblin, J. B., \& McSweeny, J. L. (1999). Prevalence of speech delay in 6-year-old children and comorbidity with language impairment. Journal of Speech, Language, and Hearing Research, 42(6), 1461-1481.

Shriberg, L. D., Austin, D., Lewis, B. A., McSweeny, J. L., \& Wilson, D. L. (1997). The percentage of consonants correct (PCC) metric: extensions and reliability data. Journal of Speech, Language, and Hearing Research, 40(4), 708-722.

Sim, H. S., Kim, Y. T., Kim, J. S., Kim, H. H., Bae, S. Y., Shin, M. J., ... Kwon, M. S. (2011). Introduction to communicative disorders. Seoul: Hakjisa.

Song, E., \& Yim, D. (2018). The effect of parent education during shared storybook reading on utterances and communication skills of children with vocabulary delay and their parents. Special Education Research, 17(2), 5-33.

Storkel, H. L. (2018). Implementing evidence-based practice: selecting treatment words to boost phonological learning. Language, Speech, and Hearing Services in Schools, 49(3), 482-496.

Storkel, H. L., \& Morrisette, M. L. (2002). The lexicon and phonology: inter- 
Kyungrang Baik, et al. • A Comparison of Treatment lexicality in the SSR for Children with SSD

actions in language acquisition. Language, Speech, and Hearing Services in Schools, 33(1), 24-37.

Swift, W. B. (1918). Speech defects in school children and how to treat them. Boston, MA: Houghton Mifflin.

Thompson, C. K., \& Shapiro, L. P. (2005). Treating agrammatic aphasia within a linguistic framework: treatment of underlying forms. Aphasiology, 19(10-11), 1021-1036.

van Riper, C. (1939). Speech correction principles and methods. Englewood Cliffs, NJ: Prentice Hall.
Whitehurst, G. J., Arnold, D. S., Epstein, J. N., Angell, A. L., Smith, M., \& Fischel, J. E. (1994). A picture book reading intervention in day care and home for children from low-income families. Developmental Psychology, 30(5), 679-689.

Wren, Y., Harding, S., Goldbart, J., \& Roulstone, S. (2018). A systematic review and classification of interventions for speech-sound disorder in preschool children. International Journal of Language \& Communication Disorders, 53(3), 446-467. 
Appendix 1. Assessment wordlist

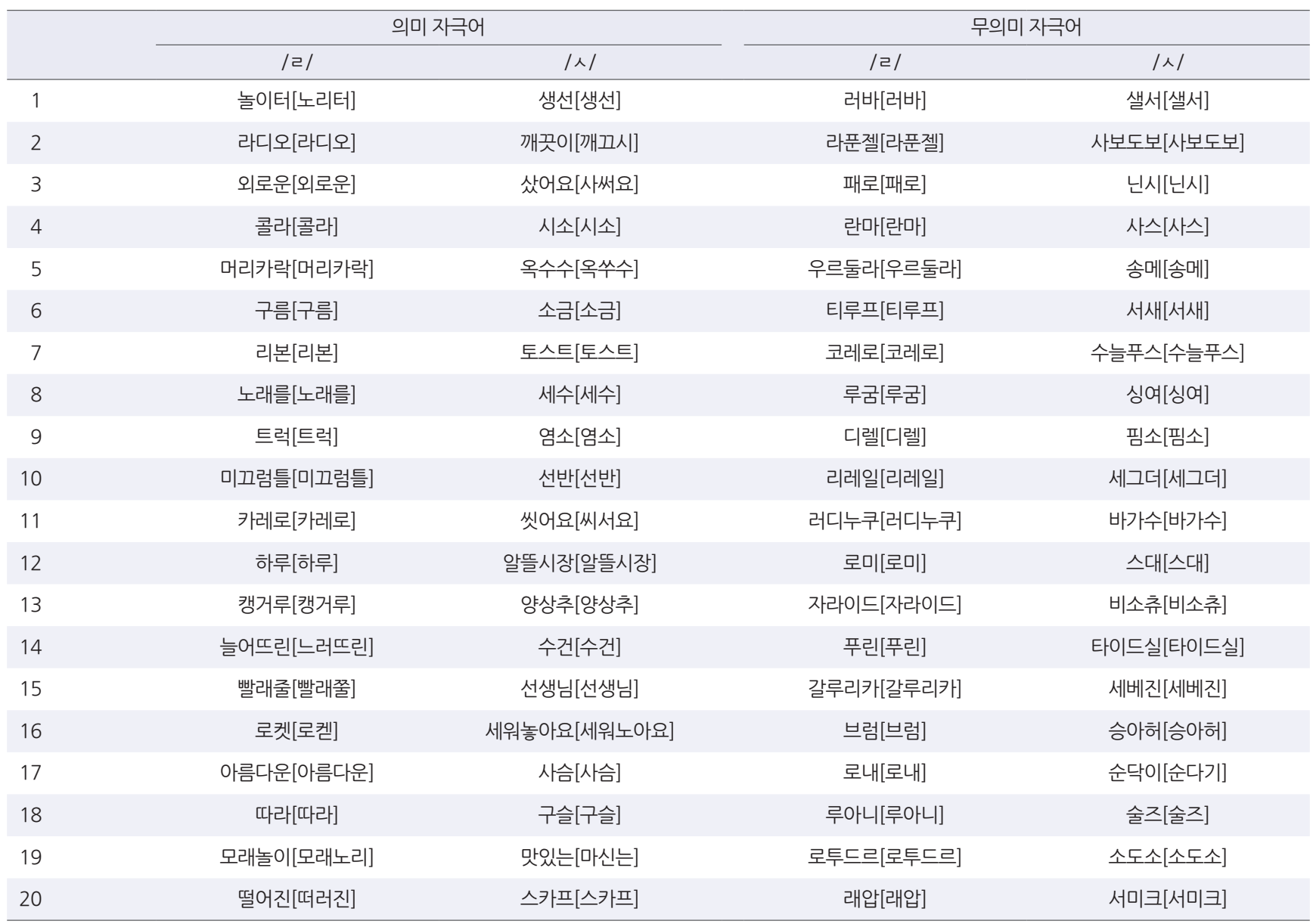




\section{국문초록}

\section{상호작용적 이야기책 읽기를 활용한 조음 중재에서의 의미 및 무의미 자극어 훈련 방법이 취학전기 말소리장애 아동의 자음정확도에 미치는 효과 비교}

백경랑 · 강진경 · 강로원 · 김영태

이화여자대학교 언어병리학과

배경 및 목적: 상호작용적 이야기책 읽기를 활용한 조음중재를 바탕으로 하여 의미 자극어 및 무의미 자극어 훈련 방법을 실시하였을 때, 두 훈련 방법 중 아동의 조음 능력 향상에 더 효과적인 방법을 알아보고자 한다. 방법: 상호작용적 이야기책 읽기를 활용한 조음 중 재 안에서 의미 자극어 훈련 방법과 무의미 자극어 훈련 방법을 교대로 실시한다. 결과: 중재 효과, 일반화, 유지에서 무의미 자극어 훈 련 방법이 의미 자극어 훈련 방법보다 더 큰 효과를 나타냈다. 논의 및 결론: 첫째, 무의미 자극어 훈련 방법은 다양한 대상자 및 목표 음소에 따라 쉽게 변형하여 적용할 수 있으므로, 대상자의 특성 및 필요에 따라 적합한 중재 방법으로 적용할 수 있다. 둘째, 상호작용 적 이야기책 읽기를 활용한 조음 중재는 치료의 중심을 아동에게 둔 중재 방법으로, 아동이 흥미를 갖는 이야기책을 사용하여 반복적 으로 상호작용적 이야기책 읽기를 활용한 조음 중재를 한다면 아동이 활동에 흥미를 가지고 적극적으로 참여할 수 있을 것이다.

핵심어: 말소리장애, 조음중재, 단어 어휘성(의미 자극어, 무의미 자극어), 상호작용적 이야기책 읽기, 개정자음정확도, 교대중재설계 본 연구는 2018년 대한민국 교육부와 한국연구재단의 지원을 받아 수행된 연구임(No. NRF-2018S1A3A2075274).

\section{참고문헌}

권회연, 송재옥, 전병운 (2017). 발달장애학생을 위한 교육용 어휘 개발 연구. 특수교육교과교육연구, 10(2), 89-122.

김광해 (2003). 등급별 국어 교육용 어휘. 서울: 박이정.

김수진, 김민정, 하승희, 하지완 (2015). 임상현장의 말소리장애 현황. Communication Sciences \& Disorders, 20(2), 133-144.

김수진, 신지영 (2015). 말소리장애. 서울: 시그마프레스.

김영태 (1992). 2-6 세 아동의 음운변동에 관한 연구 (I): 생략 및 첨가 변동을 중심으로. 재활과학연구, 10(1), 49-57.

김영태 (1996). 그림자음검사를 이용한 취학전 아동의 자음정확도 연구. 언어청각장애연구, 1(1), 7-34.

김영태, 신문자, 김수진, 하지완 (2020). 우리말 조음음운 검사2 (Urimal test of artification and phonology 2, UTAP 2). 서울: 인싸이트.

김영태, 홍경훈, 김경희, 장혜성, 이주연 (2009). 수용· 표현 어휘력 검사. 서울: 서울장애인종합복지관.

김혜원, 김영태 (2004). 이야기책을 이용한 기능적 읽기 중재가 언어발달지체아동의 의미관계확장에 미치는 효과. 언어치료연구, 13(4), 93-115.

박혜원 (2014). 한국비언어지능검사-2 (K-CTONI-2). 서울: 마인드프레스.

배소영, 곽금주 (2011). 한국판 맥아더-베이츠 의사소통 발달평가 (K M-B CDI). 서울: 마인드프레스.

송은, 임동선 (2018). 부모교육을 통한 이야기책 읽기 중재가 어휘발달지연 아동과 부모의 상호작용 및 발화에 미치는 영향. 특수교육, 17(2), 5-33.

심현섭, 김영태, 김진숙, 김향희, 배소영, 신문자, 김정미 (2011). 의사소통장애의 이해. 서울: 학지사.

이소현, 박은혜, 김영태 (2000). 교육 및 임상현장 적용을 위한 단일대상연구. 서울: 학지사.

최은아 (2003). 3세에서 8세 아동의 내용어 어휘 발달 연구. 나사렛대학교 재활복지대학원 석사학위논문.

하지완, 김수진, 김영태, 신문자 (2019). 자음정확도와 단어단위 음운지표를 이용한 일반아동의 말소리 산출능력에 대한 발달 연구. Communication

Sciences \& Disorders, 24(2), 469-477.

\section{ORCID}

백경랑(제1저자, 대학원생 https://orcid.org/0000-0002-6744-3522); 강진경(공동저자, 졸업생 https://orcid.org/0000-0002-4431-6897); 강로원(공동저자, 대학원생 https://orcid.org/0000-0001-6550-4208); 김영태(교신저자, 교수 https://orcid.org/0000-0003-1738-6862) 